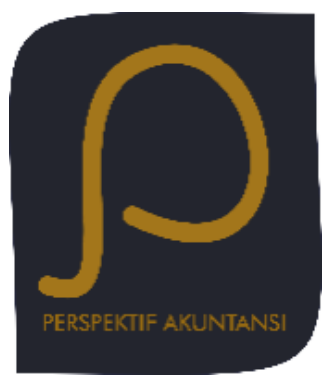

Perspektif Akuntansi

Volume 4 Nomor 1 (Februari 2021), hal. 59-74

ISSN: 2623-0194 (Print), 2623-0186 (Online)

Copyright(C) The Authors(s). All Rights Reserved

Center for Accounting Development and Research (CARD)

Fakultas Ekonomika dan Bisnis,

Universitas Kristen Satya Wacana

DOI: https://doi.org/10.24246/persi.vXiX.p59-74

http://ejournal.uksw.edu/persi

\title{
Reputasi KAP, Komite Audit Pada Integritas Laporan Keuangan Dimoderasi Komisaris Independen \& Kepemilikan Institusional
}

\author{
Ardian Christiana ${ }^{1}$ \\ Widaryanti \\ Luhgiatno \\ STIE Pelita Nusantara Semarang
}

Received

$06 / 04 / 2021$

Revised

20/04/2021

Accepted 22/04/2021
Abstract. This study aims to analyze the effect of the reputation of $K A P$ and the audit committee to integrity of financial statements with independent commissioners and institutional ownership as moderating variables. This study used secondary data from the annual reports. The population in this study eas real estate and property companies listed on the Indonesia Stock Exchange for the period 2016-2018. The sampling technique used was purposive sampling and the number of sample was 32 companies for data analysis used the SPSS 26 program. The results of this study indicated that the reputation of KAP has positive effects on integrity financial statements. The audit committees have no effect on the integrity of the financial statements. Independent Commissioners did not moderate the influence of KAP reputation and audit committee to integrity of financial statements. Institutional ownership moderates the effects of KAP reputation to integrity of financial statements. Institutional ownership moderated audits committees to the integrity of statements. The reputation of KAP and the audit committee has a simultaneous effect on the integrity of financial statements.

Keywords: Reputation of KAP, Audit Committee, Independent Commissioner, Institutional Ownership, and Integrity of Financial Statement

\footnotetext{
1 ardianchristi@gmail.com
} 


\begin{abstract}
Abstrak. Penelitian ini bertujuan untuk menganalisis pengaruh reputasi KAP, komite audit pada integritas laporan keuangan dengan komisaris independen, kepemilikan institusional sebagai pemoderasi. Populasi dalam penelitian ini adalah perusahaan real estate dan property yang terdaftar di Bursa Efek Indonesia periode 2016-2018. Pada penelitian ini menggunakan data yang berasal dari laporan tahunan. Teknik pengambilan sampel yang digunakan adalah purposive sampling dan jumlah perusahaan sampel sebanyak 32 perusahaan. Metode analisis data menggunakan program SPSS 26. Hasil Penelitian ini menunjukkan bahwa reputasi KAP berpengaruh positif terhadap integritas laporan keuangan. Komite audit tidak berpengaruh terhadap integritas laporan keuangan. Komisaris independen tidak memoderasi pengaruh reputasi KAP dan komite audit terhadap integritas laporan keuangan. Kepemilikan Institusional memoderasi pengaruh reputasi KAP dan komite audit terhadap integritas laporan keuangan. Reputasi KAP dan komite audit berpengaruh secara simultan terhadap integritas laporan keuangan.
\end{abstract}

Kata kunci: Reputasi KAP, Komite Audit, Komisaris Independen, Kepemilikan Institusional, dan Integritas Laporan Keuangan

\title{
Pendahuluan
}

Laporan keuangan sangat penting bagi perusahaan untuk menyampaikan informasi keuangan ke pihak yang berkepentingan. Oleh karena itu, laporan keuangan harus menyajikan informasi yang mudah dipahami, andal, relevansi, dan dapat diperbandingkan agar bermanfaat bagi pengguna (PSAK No. 1 Revisi, 2019). Statement Of Financial Accounting menjelaskan bahwa integritas laporan keuangan merupakan penyajian informasi laporan keuangan secara wajar tanpa kesalahan dan jujur menyajikan apa yang dimaksudkan untuk dinyatakan.

Kecurangan dalam penyajian laporan keuangan telah terjadi pada beberapa perusahaan baik luar negeri maupun dalam negeri seperti Enron, Satyam (Enron of Asia), PT Kimia Farma Tbk dan PT Kereta Api Indonesia, ketika manipulasi laporan keuangan tersebut dilakukan dengan tujuan untuk meningkatkan keuntungan perusahaan.

Fajaryani (2008) menyatakan bahwa banyak kasus yang menunjukkan lemahnya integritas laporan keuangan perusahaan melibatkan banyak pihak internal maupun pihak eksternal, yaitu akuntan publik. Kantor akuntan publik besar identik dengan KAP bereputasi tinggi dalam hal bersikap independen saat melaksanakan audit secara profesional. Dalam penelitian (Machdar \& Nurdiniah, 2018) menyatakan 
bahwa reputasi KAP memiliki pengaruh positif terhadap integritas laporan keuangan. Hal ini bertentangan dengan penelitian Gultom (2018) yang menunjukkan bahwa reputasi KAP tidak berpengaruh terhadap integritas laporan keuangan.

Keberadaan komite audit dalam perusahaan juga dapat meningkatkan integritas laporan keuangan. Komite Audit bertanggung jawab dalam memastikan laporan keuangan yang dibuat manajemen telah memberikan gambaran yang sebenarnya dan disajikan wajar sesuai prinsip akuntansi yang berterima umum. Mereka dapat meminimalkan upaya pihak manajemen melakukan manipulasi data keuangan dan prosedur akuntansi yang dapat merugikan pemegang saham eksternal dalam menjaga integritas laporan keuangan (Fajaryani, 2008). Hasil penelitian (Gultom, 2018), (Alfi et al., 2018), menyimpulkan bahwa komite audit berpengaruh terhadap integritas laporan keuangan. Namun, penelitian yang dilakukan (Indrasari et al., 2016), (Sukanto dan Widaryanti, 2018), serta (Heriadi, 2018) menyatakan bahwa komite audit tidak berpengaruh signifikansi terhadap integritas laporan keuangan.

Integritas Laporan Keuangan juga tidak terlepas dari adanya tata kelola perusahaan. Penerapan tata kelola perusahaan dengan baik akan meningkatkan integritas laporan keuangannya. Dalam hal ini corporate governance diproksi dengan komisaris independen dan kepemilikan institusional (Heriadi, 2018). Penelitian Machdar dan Nurdiniah (2018) menunjukkan bahwa komisaris independen memperkuat pengaruh reputasi kantor akuntan publik pada integritas laporan keuangan. Penelitian (Purba et al., 2018) menyatakan corporate governance mampu memoderasi pengaruh reputasi KAP dan komite audit terhadap integritas laporan keuangan. Hasil berbeda ditunjukkan oleh (Jama'an, 2008) menyatakan komisaris independen memperlemah pengaruh reputasi KAP terhadap integritas laporan keuangan. Penelitian Heriadi (2018) menunjukan corporate governance yang di proxy dengan komisaris independen dan kepemilikan institusional tidak mampu memoderasi pengaruh reputasi KAP dan komite audit terhadap integritas laporan keuangan.

Objek yang digunakan dalam penelitian ini yaitu perusahaan property dan real estate, karena perusahaan ini sangat diminati oleh para investor untuk menginvestasikan dana miliknya. Perusahaan property dan real estate mengalami kemajuan yang cukup pesat. Hal tersebut dapat dilihat dari banyaknya pembangunan secara besar-besaran, seperti pembangunan perumahan, apartemen, pusat-pusat perbelanjaan, gedunggedung perkantoran dan sebagainya. Fenomena lainnya di perusahaan property dan reals estates adalah terungkapnya kasus manipulasi laporan keuangan PT Hanson International Tbk (MYRX) yang mengakibatkan pendapatan pada laporan keuangan PT Hanson International per 31 Desember 2016 menjadi overstated dengan nilai material sebesar Rp. 613.000.000.000(Analisis Kasus Fraud PT. Hanson (2016), 2019).

Ketidakkonsistenan hasil penelitian terhadap integritas laporan keuangan memicu keinginan untuk melakukan penelitian kembali mengenai faktor yang mempengaruhi integritas laporan keuangan. Topik yang diajukan dalam penelitian ini mengenai pengaruh reputasi KAP dan komite audit terhadap 
integritas laporan keuangan dengan komisaris independen serta kepemilikan institusional sebagai faktor pemoderasi. Kemudian penelitian ini merupakan suatu studi kasus pada perusahaan property dan real estate yang Terdaftar di Bursa Efek Indonesia pada Tahun 2016-2018)". Adapun selain inkonsistensi hasil penelitian terdahulu, pembeda dalam penelitian ini dengan sebelumnya terkait integritas laporan keuangan yaitu perbedaan dalam objek dan tahun penelitian, serta adanya variabel komisaris independen adanya kepemilikan institusional sebagai pemoderasi.

Berdasarkan uraian latar belakang yang telah dipaparkan, maka rumusan masalah dalam penelitian ini sebagai berikut: Apakah reputasi KAP dan komite audit berpengaruh secara parsial maupun simultan terhadap integritas laporan keuangan? Dan apakah komisaris independen dan kepemilikan institusional memoderasi pengaruh reputasi KAP dana komite audit terhadap integritas laporan keuangan?

\section{Telaah Pustaka}

\section{Teori Keagenan}

Konsep teori keagenan (agency theory) merupakan suatu hubungan atau kontrak antara principal dan agent, dengan principal didefinisikan sebagai pihak yang memberikan mandat kepada pihak lain yang disebut agent (Rozania, 2013). Hubungan agensi bisa memicu timbulnya perkara keagenan, bila keputusan yg diambil sang agen mengenai operasi perusahaan tidak sinkron dengan tujuan principal, yaitu memaksimalkan kemakmuran prinsipal dengan pemaksimalan nilai perusahaan, melainkan demi memaksimalkan kemakmuran pribadi agen. Untuk menghindari tindakan yang mementingkan diri sendiri, adanya kontrak yang efisien.

Salah satu faktor yang harus dipenuhi dalam kontrak tersebut yaitu agen dan prinsipal memiliki informasi simetris atau sama besarnya, namun informasi yang simetris antara manajemen dan pemegang saham sangat sulit diwujudkan. Jama'an (2008) pada Heriadi (2018) menyatakan bahwa konflik keagenan bisa diminimalisasi menggunakan pemberian insentif pada agen berdasarkan kinerjanya dalam perusahaan dan melakukan supervisi berupa penyusunan laporan keuangan periodik, serta adanya fungsi auditing yang bersifat independen. Hasil audit akuntan publik sebagai pihak independen dapat memberikan keyakinan kepada prinsipal atas laporan keuangan yang disajikan agen. Di samping Itu komite audit profesional mengontrol informasi keuangan dalam perusahaan mampu mengurangi terjadinya konflik keagenan.

\section{Integritas Laporan Keuangan}

Integritas Laporan keuangan adalah laporan keuangan yang memiliki prinsip moral yang tidak memihak, memandang fakta seperti apa adanya dan mengemukakan fakta tersebut (Martani, 2014). Laporan keuangan yg memiliki integritas tinggi maka harus memenuhi dua karakteristik utama dalam laporan keuangan, yaitu relevansi (relevance) dan keandalan (reliability) ((Hardiningsih, 2010). Integritas laporan keuangan dihitung dengan model Beaver and Ryan menggunakan market book to 
value yg dihitung membagi harga pasar saham dengan nilai buku saham dimana nilai buku saham adalah total ekuitas dibagi dengan jumlah saham beredar (Machdar \& Nurdiniah, 2018):

$$
I L K i t=\frac{\text { Harga Pasar Saham }}{\text { Nilai Buku Saham }} \times 100 \%
$$

\section{Reputasi Kantor Akuntan Publik (KAP)}

Undang-undang Republik Indonesia No.05 tahun 2011 tentang Akuntan Publik (2011) mendefinisikan Kantor Akuntan Publik (KAP) sebagai badan usaha yang didirikan berdasarkan ketentuan peraturan perundang-undangan juga dapat izin usaha. Reputasi Kantor akuntan publik dapat dilihat dari adanya afiliasi dengan KAP besar yang berlaku universal atau dikenal dengan KAP Big Four. Kantor akuntan publik besar mempunyai insentif yang lebih besar untuk mengaudit dengan akurat, karena mereka memiliki lebih banyak hubungan spesifik dengan klien yang akan hilang jika laporan yang diberikan tidak akurat. KAP big four yang disebutkan adalah Deloitte Touche Tohmatsu Limited, Price Waterhouse Coopers (PwC), Ernst and Young (EY), dan Klynveld Peat Marwick Goerdeler (KPMG) International. Variabel ini diukur ini diukur dengan menggunakan variabel dummy dengan angka 1 diberikan jika auditor yang mengaudit perusahaan merupakan auditor dari KAP big four dan 0 jika perusahaan diaudit oleh KAP non big four (Machdar \& Nurdiniah, 2018).

\section{Komite Audit}

Komite audit adalah komite yang dibentuk oleh \& bertanggung jawab kepada dewan komisaris dalam membantu melaksanakan tugas dan fungsi komite audit diketuai oleh seorang komisaris independen (Peraturan Otoritas Jasa Keuangan Nomor 55/POJK.04/2015 Tahun 2015 Tentang Pembentukan dan Pedoman Pelaksanaan Kerja Komite Audit., 2015). Otoritas Jasa Keuangan mewajibkan semua emiten atau perusahaan publik membentuk komite audit minimal 3 (tiga) orang anggota yang dari komisaris independen dan pihak luar. Komite audit menggunakan pengukuran yang digunakan oleh (Machdar \& Nurdiniah, 2018) dimana komite audit sama dengan jumlah komite audit di perusahaan.

\section{Komisaris Independen}

Komisaris Independen merupakan sebuah badan dalam perusahaan yang biasanya beraanggotakan dewan komisaris indepennden yang berasal dari luar prusahaan yang berfungsi untuk menilai kinerja perusahaan secara luas dan keseluruhan (Lestariningrum, 2019). Komisaris Independen bertujuan untuk menyeimbangkan dalam pengambilan keputusan khususnya dalam rangka perlindungan terhadap pemegang saham minoritas dan pihak terkait lainnya (Susiana dan Herawati, 2007 dalam Sukanto \& Widaryanti, 2018). Dewan Komisaris paling sedikit dua orang anggota dan satu diantaranya adalah komisaris independen. Jumlah komisaris independen wajib paling sedikit 30\% dari jumlah seluruh anggota dewan komisaris. 
Komisaris Independen diukur dengan rumus berikut (Savero et al., 2012):

$$
K I N D=\frac{\text { Komisaris Independen }}{\text { Total Dewan Komisaris }} \times 100 \%
$$

\section{Kepemilikan Institusional}

Kepemilikan institusional adalah persentase jumlah saham yang dimiliki oleh pihak eksternal, seperti lembaga, perusahaan, asuransi, bank atau institusi lainnya pada akhir periode akuntansi (Tarjo, 2008, dalam Sukanto dan Widaryanti, 2018). Kepemilikan institusional diukur dari persentase antara saham yg dimiliki institusi dibagi saham beredar. Kepemilikan institusional yang tinggi membatasi manajer mengelola laba juga dapat meningkatkan integritas laporan keuangan. Kepemilikan institusional diukur dengan rumus sebagai berikut (Oktadella dan Zulaikha, 2011):

$$
K I N S T=\frac{\text { Saham Milik Institusi }}{\text { Total Saham Beredar }} \times 100 \%
$$

\section{Pengembangan Hipotesis}

Kantor akuntan publik yang memiliki reputasi baik dianggap memiliki kualitas yang baik untuk menjalankan fungsinya sebagai pihak independen untuk menyatakan kewajaran/ketidakwajaran laporan keuangan kliennya. Audit yang dilakukan secara baik dan sesuai standar audit yang berlaku, akan mengurangi kemungkinan terjadinya tindak kecurangan dalam pemeriksaan laporan keuangan dan menambah kredibilitas laporan keuangan. Kantor akuntan publik dengan reputasi baik dipercaya mampu memberikan kualitas audit yang tinggi, sehingga hasil auditnya dapat dipercaya sebagai dasar pengambilan keputusan bagi pihak berkepentingan. Dengan demikian laporan keuangan yang diaudit KAP dengan reputasi baik memiliki integritas tinggi.

$\boldsymbol{H}_{1}$ : Reputasi KAP berpengaruh positif terhadap integritas laporan keuangan.

Peran dan tanggungjawab komite audit dalam hal pelaporan keuangan adalah memonitor dan mengawasi audit laporan keuangan, memastikan agar standar dan kebijakan keuangan yang berlaku terpenuhi. Selain itu, komite audit juga harus memeriksa ulang laporan keuangan apakah sudah sesuai dengan standar dan kebijakan tersebut, apakah sudah konsisten dengan informasi lain yang diketahui oleh anggota komite audit, serta menilai mutu pelayanan dan kewajaran biaya yang diajukan auditor eksternal.

Keberadaan komite audit dapat mempengaruhi integritas laporan keuangan. Semakin banyak anggota komite audit maka upaya manajemen untuk melakukan kecurangan semakin kecil, sebaliknya apabila anggota komite semakin sedikit maka peluang manajemen untuk melakukan kecurangan semakin besar. Oleh karena itu semakin banyak jumlah komite audit maka integritas laporan keuangan akan semakin tinggi. 
$\boldsymbol{H}_{2}$ : Komite audit berpengaruh positif terhadap integritas laporan keuangan.

Komisaris independen adalah dewan komisaris perusahaan yang berasal dari pihak independen. Komisaris independen memiliki sifat integritas dan independensi yang kuat sehingga tidak mudah untuk dipengaruhi oleh manajemen dalam melakukan pengawasan terhadap laporan keuangan perusahaan. (Machdar \& Nurdiniah, 2018) menyatakan bahwa komisaris independen dalam perusahaan memperkuat pengaruh reputasi kantor akuntan publik terhadap integritas laporan keuangan. Semakin besar persentase komisaris independen maka akan memperkuat pengaruh reputasi KAP terhadap integritas laporan keuangan.

$\boldsymbol{H}_{3}$ : Komisaris independen memoderasi pengaruh reputasi KAP terhadap integritas laporan keuangan.

Keberadaan komisaris independen dalam perusahaan diharapkan mampu meningkatkan kinerja komite audit dalam mengawasi kegiatan perusahaan, sehingga dapat meningkatkan integritas laporan keuangan perusahaan. Semakin besar persentase komisaris independen diharapkan semakin meningkatkan kinerja komite audit dalam menjaga integritas laporan keuangan perusahaan, karena adanya pengawasan yang lebih besar dari komisaris independen (Purba, et al., 2018).

$\boldsymbol{H}_{4}:$ Komisaris independen memoderasi pengaruh komite audit terhadap integritas laporan keuangan.

Tindakan pengawasan perusahaan oleh pihak investor institusional dapat mendorong manajer untuk lebih memfokuskan perhatiannya terhadap kinerja perusahaan sehingga akan mengurangi perilaku mementingkan diri sendiri, sehingga manajemen akan memilih KAP dengan reputasi yang baik untuk meyakinkan investor institusional bahwa laporan keuangan yang disajikan berintegritas. Dengan demikian, semakin tinggi persentase kepemilikan institusional diharapkan akan memperkuat pengaruh reputasi KAP terhadap integritas laporan keuangan (Machdar dan Nurdiniah, 2018).

$\boldsymbol{H}_{5}$ : Kepemilikan institusional memoderasi pengaruh reputasi KAP terhadap integritas laporan keuangan.

Kepemilikan institusi lain diharapkan semakin meningkatkan kinerja komite audit untuk menjaga integritas laporan keuangan perusahaan. Dengan kepemilikan institusional. Semakin besar kepemilikan institusional maka komite audit akan lebih berhati-hati dalam mengawasi manajemen agar menyajikan informasi yang sebenarnya, sehingga laporan keuangan yang dihasilkan oleh manajemen lebih berintegritas (Purba et al., 2018).

$\boldsymbol{H}_{6}$ : Kepemilikan institusional memoderasi pengaruh komite audit terhadap integritas laporan keuangan 


\section{Model Penelitian}

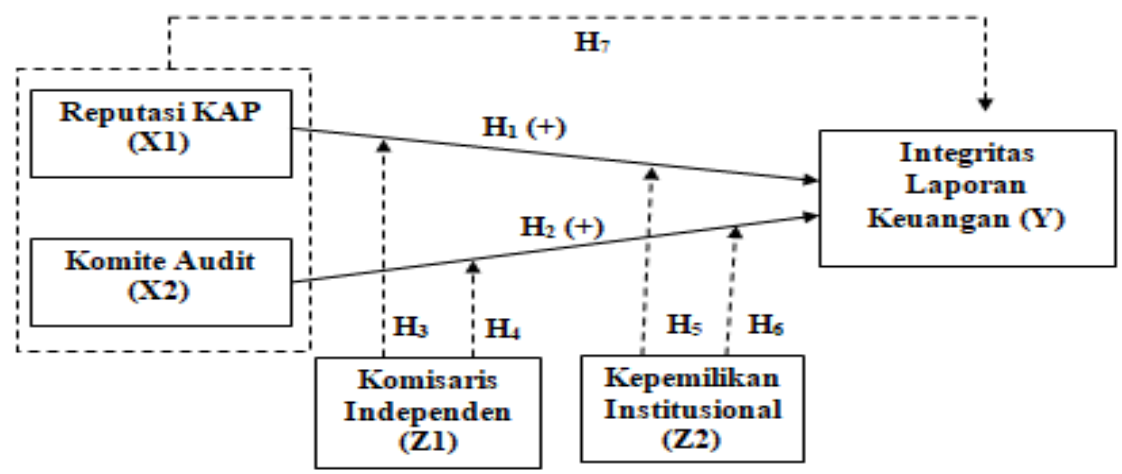

Gambar 1. Model Penelitian

\section{Metoda}

\section{Jenis dan Sumber Data}

Jenis data yang digunakan dalam penelitian ini adalah data sekunder berupa annual report (laporan tahunan) perusahaan property dan real estate di BEI selama tahun 2016-2018. Data diperoleh dari penelitian ini berasal dari IDX statistik dan www.idx.co.id.

\section{Populasi dan Sampel}

Populasi dalam penelitian ini adalah perusahaan property dan real estate yang terdaftar di Bursa Efek Indonesia periode 2016-2018. Metode pengambilan sampel yang digunakan dalam penelitian ini adalah purposive sampling dengan kriteria: 1) Terdaftar sebagai perusahaan sektor property dan real estate di BEI selama tahun 2016-2018. 2) Perusahaan sektor property dan real estate secara konsisten menerbitkan annual report berturut-turut selama tahun 2016-2018.3) Perusahaan menyampaikan data sesuai dengan variabel yang dipakai selama periode penelitian.

\section{Hasil dan Pembahasan}

\section{Hasil}

Analisis Statistik Deskriptif

Hasil uji statistik deskriptif menunjukan bahwa dari 96 sampel perusahaan property dan real estate nilai minimum integritas laporan keuangan sebesar 9\%, nilai maksimum sebesar 199,3\%. Nilai rata-rata (mean) sebesar 69,7\% dan standar deviasi sebesar 39\%. Hasil uji frekuensi reputasi KAP diketahui bahwa dari 96 sampel perusahaan properti dan real estate yang diteliti terdapat 22,9\% yang diaudit oleh KAP big four atau yang berafiliasi, sedangkan 77,1\% diaudit oleh KAP non big four. Hasil uji statistik deskriptif menunjukan bahwa dari 96 sampel 
perusahaan properti dan real estate variabel komite audit memiliki nilai minimum sebanyak dua orang, nilai maksimum sebanyak tiga orang, dan standar deviasi sebesar 0,0326793 .

Kemudian nilai rata-rata sebesar 2,885417 yang artinya sebagian besar perusahaan yang diteliti memiliki anggota komite audit sebanyak 3 orang. Hasil uji statistik deskriptif menunjukan bahwa dari 96 sampel perusahaan properti dan real estate variabel komisaris independen memiliki nilai minimum sebesar 20\%, nilai maksimum 83\%, dan standar deviasi sebesar 0,0106525. Variabel komisaris independen mempunyai nilai rata-rata sebesar 0,409688 atau 40\%. Hasil uji statistik deskriptif menunjukan bahwa dari 96 sampel perusahaan properti dan real estate variabel kepemilikan institusional memiliki nilai minimum sebesar 9\%, nilai maksimum sebesar 98\%, serta standar deviasi sebesar 2\%. Variabel kepemilikan institusional mempunyai nilai rata-rata sebesar $64 \%$.

\section{Uji Asumsi Klasik}

Berdasarkan Tabel 1 diketahui bahwa model regresi dalam penelitian ini berdistribusi normal dengan nilai signifikansi sebesar 0,111>0,05.

Tabel 1. Hasil Uji Asumsi Klasik

\begin{tabular}{cccccc}
\hline Normalitas & $\begin{array}{c}\text { Asymp. Sig. (2- } \\
\text { tailed) }\end{array}$ & & & ,111 & \\
& RKAP & KA & KIND & KINST \\
Multikolinieritas & Tolerance &, 934 &, 905 &, 928 &, 944 \\
& VIF & 1,070 & 1,105 & 1,078 & 1,059 \\
Heteroskedastisitas & Sig. &, 365 &, 222 &, 175 &, 095 \\
Autokorelasi & $\begin{array}{c}\text { Durbin- } \\
\text { Watson }\end{array}$ & & & 1,786 & \\
& Wuts & & & & \\
\hline
\end{tabular}

Sumber: Data Diolah (2020)

Penelitian ini tidak terjadi multikolinieritas karena nilai tolerance $>0,10$ dan nilai VIF $<10$ untuk semua variabel. Penelitian ini tidak terjadi heteroskedastisitas karena nilai sig. > 0,05 untuk semua variabel. Posisi nilai Durbin-Watson berada diantara dU dan (4-dU) yaitu 1,755 1,786 2,245 sehingga dapat disimpulkan bahwa data dalam penelitian ini tidak terjadi autokorelasi. 


\section{Uji Hipotesis}

Berdasarkan tabel 2 maka persamaan regresi dalam penelitian ini dapat dijelaskan sebagai berikut:

ILK $=0,462+0,506$ RKAP - 0,064 KA - 0,154 RKAP_KIND + 0,053 KA_KIND - 0,688 RKAP_KINST $+0,209$ KA_KINST $+\varepsilon$

Tabel 2. Hasil Uji Hipotesis

\begin{tabular}{|c|c|c|c|c|c|c|c|c|}
\hline & & Const. & RKAP & $\mathrm{KA}$ & $\begin{array}{c}\text { RKAP_KI } \\
\text { ND }\end{array}$ & $\begin{array}{c}\text { KA_KI } \\
\text { ND }\end{array}$ & $\begin{array}{c}\text { RKAP_KI } \\
\text { NST }\end{array}$ & $\begin{array}{c}\text { KA_KIN } \\
\text { ST }\end{array}$ \\
\hline \multirow[t]{4}{*}{$\begin{array}{l}\text { Unstd. } \\
\text { Coeff. }\end{array}$} & B & , 462 & ,506 & , &,- 154 & ,053 &,- 688 & ,209 \\
\hline & $\begin{array}{l}\text { Std. } \\
\text { Err }\end{array}$ & ,251 & ,250 & 106 & 152 & ,104 & 263 & ,050 \\
\hline & $\begin{array}{c}\text { or } \\
\mathrm{t}\end{array}$ & 1,843 & 2,024 & - 604 & $-1,013$ & ,516 & $-2,621$ & 4,192 \\
\hline & Sig. & ,070 & 070 & ,548 & 315 & 608 & 011 & ,000 \\
\hline$F_{\text {hitung }}$ & & & & & 14,058 & & & \\
\hline Sig. F & & & & & 0,000 & & & \\
\hline $\begin{array}{l}\text { Adjusted } \\
\text { R Square }\end{array}$ & & & & & .370 & & & \\
\hline
\end{tabular}

Selanjutnya pada Tabel 2 dapat dilihat bahwa uji t untuk H1 menunjukkan nilai $\mathrm{t}$ hitung sebesar 2,024 dengan derajat signifikansi sebesar 0,047, maka H1 diterima. Uji $\mathrm{t}$ untuk $\mathrm{H} 2$ menunjukkan nilai $\mathrm{t}$ hitung sebesar -0,604 dengan derajat signifikansi sebesar 0,548, maka H2 ditolak. Uji $t \quad H 3$ menunjukkan nilai thitung sebesar $-1,013$ derajat signifikansi 0,315, maka H3 ditolak. Uji t untuk H4 menunjukkan nilai thitung sebesar 0,516 dengan derajat signifikansi sebesar 0,608, maka H4 ditolak. Uji t untuk H5 menunjukkan nilai $t$ hitung sebesar -2,621 dengan derajat signifikansi sebesar 0,011, maka H5 ditolak. Uji $t$ untuk H6 menunjukkan nilai $t$ hitung sebesar 4,196 dengan derajat signifikansi sebesar 0,000, maka H6 diterima. Hasil uji F pada tabel 3 menunjukkan signifikansi pada tingkat 0,000 dan Fhitung 14,058 maka $\mathrm{H} 7$ diterima. Kemudian, berdasarkan Tabel 2 dapat diketahui nilai Adjusted $R$ Square sebesar 0,370 atau $37 \%$. Dengan demikian integritas laporan keuangan dapat dijelaskan oleh 2 variabel independen yaitu reputasi KAP dan komite audit dengan di moderasi oleh komisaris independen dan kepemilikan institusional sebesar $37 \%$, sedangkan sisanya yaitu $63 \%$ dijelaskan oleh variabel lain yang tidak dimasukkan dalam penelitian. 


\section{Pembahasan}

\section{Pengaruh Reputasi KAP Terhadap Integritas Laporan Keuangan}

Berdasarkan hasil pengujian disimpulkan bahwa reputasi KAP berpengaruh positif dan signifikan terhadap integritas laporan keuangan pada perusahaan property dan real estate pada periode 2016-2018. Hasil audit akuntan publik sebagai pihak independen dapat memberikan keyakinan kepada prinsipal atas laporan keuangan yang disajikan oleh agen. Kantor akuntan publik Big Four termasuk KAP yang memiliki reputasi baik di dunia Internasional. Mereka memiliki reputasi baik karena jaringannya tersebar luas didunia serta memiliki auditor yang kompeten dan telah berpengalaman. Pihak investor akan lebih yakin atau percaya dengan perusahaan yang menggunakan jasa audit KAP Big Four. Dengan demikian KAP dengan reputasi baik dapat menghasilkan laporan keuangan yang memiliki integritas tinggi.

Hasil pengujian menunjukan arah pengaruh positif berarti bahwa perusahaan yang telah menggunakan jasa KAP Big Four menyajikan laporan keuangan berintegritas. Hasil ini sesuai dengan teori keagenan yang digunakan dalam penelitian ini dengan adanya akuntan publik yang memiliki reputasi baik dapat memberikan keyakinan bagi prinsipal terhadap integritas laporan keuangan perusahaan. Hasil ini juga didukung dengan data dimana sebesar 22,9\% perusahaan dalam yang diteliti diaudit oleh KAP big four atau berafiliasi memiliki nilai persentase integritas laporan keuangan yang cukup tinggi. Penemuan ini mendukung penelitian sebelumnya yang dilakukan oleh Machdar dan Nurdiniah, (2018), Purba et al. (2018), dan Heriadi (2018). Hasil penelitian mereka menyatakan bahwa reputasi KAP memiliki pengaruh positif terhadap integritas laporan keuangan.

\section{Pengaruh Komite Audit Terhadap Integritas Laporan Keuangan}

Berdasarkan hasil pengujian disimpulkan bahwa komite audit tidak berpengaruh terhadap integritas laporan keuangan perusahaan. Keberadaan komite audit kurang efektif karena jumlah komite audit di perusahaan belum tentu dapat memaksimalkan fungsinya dalam praktik akuntansi. Komite audit disinyalir hanya melakukan penelaahan atas informasi keuangan dan akuntansi yang akan dikeluarkan perusahaan, tetapi tidak langsung terlibat dalam menyelesaikan masalah keuangan yang dihadapi oleh perusahaan. Jumlah komite audit yang banyak dapat mempengaruhi penilaian atas informasi keuangan dan akuntansi perusahaan karena semakin banyak orang yang terlibat di dalamnya sehingga hasil yang diperoleh kurang maksimal.

Selain itu, pengukuran komite audit dalam penelitian ini hanya menghitung jumlah komite audit dalam perusahaan yang diteliti. Hal tersebut disinyalir kurang mampu untuk menilai pengaruh komite audit terhadap integritas laporan keuangan. Hasil ini bertentangan dengan hipotesis yang telah dibuat dalam penelitian ini dimana diharapkan semakin banyak jumlah komite audit maka akan semakin baik integritas laporan keuangan. Berdasarkan teori keagenan keberadaan komite audit dapat 
membantu untuk mengontrol informasi keuangan dalam perusahaan juga mampu mengurangi terjadinya konflik keagenan. Namun berdasarkan hasil penelitian ini meskipun sebagian besar perusahaan yang diteliti memiliki jumlah komite audit sebanyak 3 orang, hal tersebut tidak dapat menentukan integritas laporan keuangan. Penemuan ini mendukung penelitian (Indrasari et al., 2016), (Sukanto \& Widaryanti, 2018), serta (Heriadi, 2018). Hasil penelitian mereka menyatakan bahwa komite audit tidak berpengaruh signifikan terhadap integritas laporan keuangan.

\section{Komisaris Independen Memoderasi Reputasi KAP Terhadap Integritas Laporan Keuangan}

Berdasarkan hasil pengujian disimpulkan bahwa komisaris independen tidak memediasi pengaruh reputasi KAP terhadap integritas laporan keuangan perusahaan. Persentase komisaris independen dalam perusahaan tidak mempengaruhi reputasi KAP terhadap integritas laporan keuangan yang disajikan untuk pihak yang membutuhkan laporan keuangan perusahaan. Tugas dan fungsi komisaris independen tidak berpengaruh langsung terhadap bagianbagian dalam pengukuran integritas laporan keuangan. Disamping itu, kantor akuntan publik bekerja secara independen sehingga tidak dapat dipengaruhi oleh pihak lain. Penemuan ini konsisten dengan penelitian (Heriadi, 2018) dan (Purba et al., 2018). Hasil penelitian mereka menyatakan komisaris independen tidak mampu memperkuat pengaruh reputasi KAP terhadap integritas laporan keuangan perusahaan.

\section{Komisaris Independen Memoderasi Komite Audit Terhadap Integritas Laporan Keuangan}

Berdasarkan hasil pengujian disimpulkan bahwa komisaris independen tidak memoderasi pengaruh komite audit terhadap integritas laporan keuangan perusahaan. Besar atau kecilnya persentase komisaris independen kurang efektif untuk membantu kinerja komite audit dalam menjaga integritas laporan keuangan perusahaan. Hasil ini tidak sejalan dengan Otoritas Jasa Keuangan (2014), yang menyatakan bahwa tugas komisaris independen adalah melakukan pengawasan dan bertanggung jawab atas pengawasan terhadap kebijakan pengurusan, jalannya pengurusan pada umumnya, baik mengenai Emiten atau Perusahaan Publik maupun usaha Emiten atau Perusahaan Publik, dan memberi nasihat kepada Direksi. Keberadaan komisaris independen dalam perusahaan disinyalir hanya sebagai pemenuh regulasi dan peraturan pemerintah tetapi tidak dapat menegakan tata kelola yang baik. Penemuan ini konsisten dengan hasil penelitian (Heriadi, 2018). Dalam penelitiannya Heriadi menyatakan bahwa komisaris independen tidak mampu memperkuat pengaruh komite audit terhadap integritas laporan keuangan.

\section{Kepemilikan Institusional Memoderasi Reputasi KAP Terhadap Integritas Laporan Keuangan}

Berdasarkan hasil pengujian menunjukkan bahwa kepemilikan institusional secara signifikan memperlemah pengaruh reputasi KAP terhadap integritas 
laporan keuangan perusahaan. Perusahaan yang memiliki persentase kepemilikan institusional yang tinggi dan menggunakan jasa KAP big four atau afiliasinya belum tentu mampu meningkatkan integritas laporan keuangan. Hal ini karena terjadinya beberapa skandal kecurangan dalam laporan keuangan yang dilakukan oleh perusahaan besar yang menggunakan jasa KAP big four. Penemuan ini konsisten dengan hasil penelitian (Heriadi, 2018) dan (Purba et al., 2018). Hasil penelitian mereka menyatakan bahwa kepemilikan institusional tidak dapat memperkuat pengaruh komite audit terhadap integritas laporan keuangan perusahaan.

\section{Kepemilikan Institusional Memoderasi Komite Audit Terhadap Integritas Laporan Keuangan}

Berdasarkan hasil pengujian menunjukkan bahwa kepemilikan institusional secara signifikan memperkuat pengaruh komite audit terhadap integritas laporan keuangan perusahaan. Semakin besar kepemilikan institusional maka komite audit akan lebih berhati-hati dalam mengawasi manajemen agar menyajikan informasi yang sebenarnya, sehingga laporan keuangan yang dihasilkan oleh manajemen lebih berintegritas. Hal ini karena, dalam sebuah perusahaan komite audit mengawasi dan melindungi hak-hak pihak di luar manajemen perusahaan. Tindakan monitoring yang lebih optimal dapat memperkecil peluang terjadinya tindakan kurang baik yang dilakukan oleh manajer dan manajer akan lebih berhati-hati dalam mengambil keputusan. Penemuan ini sejalan dengan hasil penelitian Purba et al. (2018). Hasil penelitian mereka menyatakan bahwa kepemilikan institusional dapat memperkuat pengaruh komite audit terhadap integritas laporan keuangan perusahaan.

\section{Simpulan}

Berdasarkan hasil penelitian dapat disimpulkan bahwa reputasi KAP berpengaruh positif terhadap integritas laporan keuangan perusahaan. Komite audit tidak berpengaruh terhadap integritas laporan keuangan perusahaan. Komisaris independen tidak memoderasi pengaruh reputasi KAP dan komite audit terhadap integritas laporan keuangan perusahaan. Kepemilikan institusional memoderasi pengaruh reputasi KAP dan komite audit terhadap integritas laporan keuangan perusahaan. Reputasi KAP dan komite audit berpengaruh secara simultan terhadap integritas laporan keuangan. Penelitian selanjutnya disarankan dapat menambah variabel lain yang diduga dapat mempengaruhi integritas laporan keuangan serta menambahkan aspek seperti independensi komite audit, jumlah pertemuan komite audit, dan lain-lain untuk mengukur variabel komite audit. 


\section{Daftar Pustaka}

Alfi, R., Siska, Q., Yudowati, P., Bandung, T., Telekomunikasi, J., Buah Batu, T., Kolot, D., \& Barat, J. (2018). Pengaruh Mekanisme Corporate Governance Dan Kualitas Audit Terhadap Integritas Laporan Keuangan Pada Perusahaan Pertambangan Di Bursa Efek Indonesia.

Fajaryani, A. (2008). Analisis Faktor-Faktor Yang Mempengaruhi Integritas Terdaftar Di Bursa Efek Indonesia Periode 2008-2013).

Gultom, R. (2018). Pengaruh Tata Kelola Perusahaan, Reputasi Kap, Ukuran Perusahaan, Dan Leverage Terhadap Integritas Laporan Keuangan (Studi Empiris Pada Perusahaan Manufakturyang Terdaftar Di Bei Tahun 2014-2016).

Hardiningsih, P. (2010). Pengaruh Independensi, Corporate Governance, Dan Kualitas Audit Terhadap Integritas Laporan Keuangan. Kajian Akuntansi.

Heriadi, W. (2018). Pengaruh Komite Audit Dan Reputasi Kantor Akuntan Publik Terhadap Integritas Laporan Keuangan Dengan Corporate Governance Sebagai Pemoderasi (Studi Empiris Pada Perusahaan Jasa Keuangan Yang Terdaftar Di Bursa Efek Indonesia Tahun 2016).

Indrasari, A., Yuliandhari, W. S., Dedik, D., \& Triyanto, N. (2016). Pengaruh Komisaris Independen, Komite Audit, Dan Financial Distress Terhadap Integritas Laporan Keuangan. Jurnal Akuntansi, Xx. Www.Ojk.Go.Id

Analisis Kasus Fraud Pt. Hanson (2016), (2019).

Jama'an. (2008). Pengaruh Mekanisme Corporate Governance Dan Kualitas Kantor Akuntan Publik Terhadap Integritas Informasi Laporan Keuangan Diponegoro Desember 2008 Pernyataan Keaslian Tesis. Tesis, 1-52.

Lestariningrum, S. (2019). The Influence Of Institusional Ownership, Managerial Ownership, Independent Commissioners, And Audit Committees of The Integrity of Financial Statement.

Machdar, N. M., \& Nurdiniah, D. (2018). The Influence Of Reputation Of Public Accounting Firms On The Integrity Of Financial Statements With Corporate Governance As The Moderating Variable. Binus Business Review, 9(3), 177-186. Https://Doi.Org/10.21512/Bbr.V9i3.4311

Martani, D. . (2014). Akuntansi Keuangan Menengah Ii. Salemba Empat.

Peraturan Otoritas Jasa Keuangan No. 33/Pojk.04/2014 Tentang Direksi Dan Dewan Komisaris Emiten Atau Perusahaan Publik. (N.D.).

Peraturan Otoritas Jasa Keuangan Nomor 55/Pojk.04/2015 Tahun 2015 Tentang Pembentukan Dan Pedoman Pelaksanaan Kerja Komite Audit.

Psak No. 1 Revisi 2019 Tentang Penyajian Laporan Keuangan.

Purba, E. E., Darlis, E., \& Wiguna, M. (2018). Pengaruh Reputasi Kap, Komite Audit Dan Pergantian Auditor Terhadap Integritas Laporan Keuangan Dengan Pemoderasi Corporate Governance (Studi Empiris Pada Perusahaan Pertambangan Yang Terdaftar Di Bursa Efek Indonesia Tahun 2012-2016).

Rozania, Et Al. (2013). Pengaruh Mekanisme Corporate Governance, Pergantian Auditor, Dan Spesialisasi Industri Auditor Terhadap Integritas Laporan Keuangan.

Savero, D. O., Nazir, A., \& Safitri, D. (2012). Pengaruh Komisaris Independen, Komiteaudit, Kepemilikan Instutisional Dankepemilikan Manajerialterhadap Integritas Laporan Keuangan (Studi Empiris Pada Perusahaan Manufaktur Yang Terdaftar Di Bursa Efek Indonesia Tahun 2012-2014). Jom Fekon, 4(1), 2017. 
Sukanto, E., \& Widaryanti). (2018). Analisis Pengaruh Ukuran Kap Dan Tata Kelola Perusahaan Terhadap Integritas Laporan Keuangan (Studi Kasus Pada Perusahaan Sektor Properti Dan Real Estate Yang Terdaftar Di Bei Periode 2013-2015). Juni, 13(1), 2044.

Undang-Undang Republik Indonesia No 05 Tahun 2011 Tentang Akuntan Publik. 
